\title{
The platacanthomyine rodent Neocometes from the Miocene of South Korea and its paleobiogeographical implications
}

\author{
Yuong-Nam Lee and Louis L. Jacobs \\ Acta Palaeontologica Polonica 55 (4), 2010: 581-586 doi: http://dx.doi.org/10.4202/app.2010.0013
}

A left first lower molar of Neocometes from the Bukpyeong Formation, South Korea is more similar to Neocometes similis and Neocometes cf. similis from Europe than to Neocometes orientalis from Thailand, and is therefore referred to Neocometes aff. similis. The new discovery of Neocometes is important in that it is the first evidence in Asia to show close faunal affinity to European Neocometes . It is also of paleobiogeographic significance for the subfamily

Platacanthomyinae, because it represents the easternmost occurrence of this subfamily in Eurasia, implying there was continuous gene flow between the Neocometes populations of eastern Asia and western Europe. The paleoclimatic interpretation for the Bukpyeong Formation based on the palynomorphs implies that Neocometes had wider climatic tolerances than either of the two extant platacanthomyine genera. The evolutionary stage of Korean Neocometes is comparable to material from European localities correlated with MN 4 and MN 5, which constrains the age of the Bukpyeong Formation to between 18 and 15.2 Mya.

Key words: Mammalia, Rodentia, Platacanthomyinae, Neocometes, paleobiogeography, Miocene, Bukpyeong Formation, South Korea.

Yuong-Nam Lee [ylee@kigam.re.kr], Korea Institute of Geoscience and Mineral Resources, Daejeon 305-350, South Korea; Louis L. Jacobs [jacobs@mail.smu.edu], Roy M. Huffington Department of Earth Sciences, Southern Methodist University, Dallas, TX 75275, USA.

This is an open-access article distributed under the terms of the Creative Commons Attribution License (for details please see creativecommons.org), which permits unrestricted use, distribution, and reproduction in any medium, provided the original author and source are credited. 
Fof Full text $(247.7 \mathrm{kB})$ 